\title{
RELEVANSI PEMIKIRAN IRIGARAY TERHADAP ARSITEKTUR
}

\author{
Nurhijrah $^{1}$, Tamiya M. S. Kasman ${ }^{2}$, Boyke M. Akbar ${ }^{3}$ \\ Program Studi Teknik Sipil, Fakultas Teknik/Universitas Andi Djemma1, \\ Program Studi Arsitektur, Fakultas Teknik Sipil dan Perencanaan/ Universitas Gunadarma², \\ PT Bita Bina Semesta Bandung 3 \\ e-mail: *1nurhijrahbakri@yahoo.com,2tamiya.kasman@gmail.com,33boyke_m@bita.co.id
}

\begin{abstract}
Abstrak_ Teori arsitektur terlahir dari beberapa pemikiran filosof yang membahas tentang hubungan manusia dengan ruang. Pemikiran para filosof tersebut, menjelaskan bagaimana memahami manusia sebagai pengguna produk arsitektur. Berbagai pemikiran tersebut kemudian diterjemahkan oleh para praktisi dan mahasiswa arsitektur ke dalam konsep perancangan yang lebih humanis. Tulisan ini bertujuan mendiskripsikan pemikiran salah satu filosof yang berkontribusi pada perkembangan teori arsitektur, yaitu Luce Irigaray. Pemikiran Irigaray mengenai feminisme akan dijelaskan bagaimana relevansinya terhadap konsep desain arsitektur. Tulisan ini disusun dengan metode kajian literatur dengan mengkaji dua pemikiran Irigaray yaitu mengenai konsep fluiditas dan persepsi melalui sentuhan. Adapun hasil kajian dari kedua konsep hasil pemikiran Irigaray, yaitu fluiditas dan persepsi melalui sentuhan, keduanya menjelaskan bagaimana perbedaan gender dalam suatu ruang menentukan bentukan dari suatu produk arsitektur. Apabila arsitek telah dapat mewadahi perbedaan kebutuhan antar gender, maka karya tersebut telah mengakui kedua gender sebagai subyek yang diwadahi dalam suatu produk arsitektural, bukanlah lagi sebagai objek. Sehingga tercipta suatu karya arsitektur yang lebih humanis.
\end{abstract}

Kata kunci: Irigaray; Feminisme; Teori Arsitektur.

\begin{abstract}
Architectural theory was born from several philosophical thoughts which discussed the relationship between humans and space. The thought of the philosophers explained how to understand humans as users of architectural products. These various thoughts were then translated by architectural practitioners and students into more humanistic design concepts. This paper aims to describe the thoughts of one of the philosophers who contributed to the development of architectural theory, Luce Irigaray. Irigaray thinking about feminism will explain how relevant it is to architectural design concepts. This paper is compiled with a literature review method by examining two irrational thoughts, the concept of fluidity and perception through touch. The results of the study of the two concepts of Irigaray's thinking, fluidity and perception through touch, both explain how gender differences in a space determine the formation of an architectural product. If the architect has been able to accommodate differences in needs between genders, then the work has recognized the two genders as subjects that are contained in an architectural product, no longer as objects. Thus creating a more humanistic architectural work.
\end{abstract}

Keywords: Irigaray; Feminism; Architecture Theory.

\footnotetext{
${ }^{1}$ Program Studi Teknik Sipil, Fakultas Teknik/Universitas Andi Djemma

${ }^{2}$ Program Studi Arsitektur, Fakultas Teknik Sipil dan Perencanaan/ Universitas Gunadarma

${ }^{3}$ PT Bita Bina Semesta Bandung
} 


\section{PENDAHULUAN}

Luce Irigaray adalah filosof berkebangsaan Prancis yang lahir di Belgia pada tanggal 3 Mei 1932, menerima gelar master pada tahun 1955 dari Universitas Louvain dan selanjutnya berprofesi sebagai pengajar pada sekolah tinggi di Brussels dari tahun 1956-1959. Pada tahun 1960, Irigaray menghadiri seminar psikoanalisis dari Jacques Lacan dan mulai bergabung dengan École Freudienne de Paris yang diasuh oleh Lacan. Selanjutnya, Ia berhasil meraih gelar Doktor pada bidang linguistik dan filosofi terkait feminisme. Irigaray pun sempat mengajar di University of Vincennes.

Karya pertama Irigaray berjudul Speculum of the Other Woman diterbitkan pada tahun 1974. Dalam karya ini, Irigaray menunjukkan pemikirannya yang mengkritik psikoanalisa Freudian dan Lacanian dengan mengatakan bahwa kedua pemikiran ini dilatar belakangi pola pikir yang khas maskulin dan mengkritik ciri phallagosentrisme filsafat yang ada pada kedua pemikiran psikoanalisa tersebut. Hal ini membuat Irigaray mendapatkan pengakuan sekaligus pemecatan dari tempat kerjanya. Tanpa menghiraukan hambatan tersebut, Irigaray akhirnya menjadi sosok yang berpengaruh dan menjadi penulis yang banyak berkarya di dalam ruang feminis kontemporer dan filsafat kontinental.

Karya Irigaray sejak tahun 1974 sampai saat ini dapat dibedakan dalam dua fase. Fase pertama, penolakan Irigaray terhadap kebudayaan modern barat terkait hubungan sosial dan gender yang dibangun dalam filosofi dan psikologi. Fase kedua, ditandai oleh kritik intensif ditandai dengan "perbedaan seksual" terhadap konstruksi fisik dan psikologi pada gender di budaya barat. Secara prinsip, kedua fase ini melibatkan analisis filosofis, psikologis, dan bahasa untuk memperlihatkan bagaimana pengaruhnya terhadap pengalaman psikis dan fisik pria dan wanita.

Sejak awal penerbitannya hingga sekarang, karya-karya Irigaray tersebut dapat dikelompokkan dalam beberapa tema. Karya tahun 1973 hingga tahun 1980an bertema tentang struktur, bahasa, dan ekspresi yang mempengaruhi secara langsung maupun tidak langsung, serta gagasan budaya tentang bagaimana lelaki dan perempuan mengekspresikan diri mereka. Awal 1980 hingga tahun 1990 bertema gaya tulis puitis yang mengeksplorasi perbedaan seksual secara fisik (isu tubuh) dan psikis (isu hasrat dan bahasa). Tema ketiga yaitu pada akhir tahun 1990 hingga sekarang berupa perdebatan politis, sosial, dan budaya tentang gender di luar lingkup akademik dalam konteks konstruksi politis dan budaya mengenai identitas dan citizenship

Irigaray termasuk dalam pembawa gerakan feminisme generasi ketiga yang tidak sekadar mempertanyakan ketidaksetaraan sosial yang dialami kaum perempuan, melainkan mengamati struktur ideologis yang sudah tertanam lama dan membuat perempuan berada dalam posisi yang tidak menguntungkan dibandingkan laki-laki. Prabasmoro (2005) mengemukakan bahwa Irigaray mengetengahkan tidak saja perbedaan seksual perempuan dari laki-laki, tetapi juga mengembalikan kebanggaan perempuan pada tubuh dan proses yang berlangsung di dalam tubuhnya yaitu darah, reproduksi, dan pluralitas. Dalam tulisan ini akan dipaparkan relevansi pemikiran Irigaray mengenai feminisme terutama mengenai perbedaan tubuh gender dengan arsitektur.

\section{METODE}

Tulisan ini disusun dengan metode kajian literatur. Beberapa tulisan ilmiah mengenai pemikiran Irigaray dikumpulkan dan dikaji sesuai dengan tujuan yang diinginkan yaitu mencari relevansi pemikiran Irigaray dengan arsitektur. Data literatur yang telah dikumpulkan kemudian dianalisis secara deskriptif untuk menjelaskan bagaimana Irigaray menerjemahkan perbedaan 


\section{HASIL DAN PEMBAHASAN}

\section{A. Pemikiran Irigaray tentang Perbedaan Gender}

Berbeda dengan gerakan feminis pertama, Irigaray mengajukan konsep perbedaan seksual sebagai basis pembebasan perempuan. Hal ini disebabkan adanya kenyataan realitas konkrit keterpinggiran kaum perempuan, bukan hanya akibat dominasi bahasa patriarkis melainkan juga oleh berbagai slogan yang mengatasnamakan kesetaraan lelaki-perempuan dan slogan kenetralan dalam klausul berbagai konvensi dan perundang-undangan. Menurutnya, slogan-slogan kesetaraan itu sudah menjadi candu bagi masyarakat dan suguhan ilusi bagi kemajuan.

Di dalam kata pengantar edisi Perancis untuk bukunya yang berjudul Thinking the Difference for a Peaceful Revolution, Irigaray dengan jelas membahas Deklarasi HAM PBB dimana ketentuan-ketentuan yang ada di dalamnya dianggap telah mengingkari realitas keseharian kaum perempuan. Bukan hanya itu, menurut Irigaray, Deklarasi HAM bukanlah poin-poin normatif yang bersifat netral secara ideologis, melainkan sepenuhnya didefinisikan oleh kepentingan kaum lelaki.

Keunikan yang segera tampak setelah membaca karyanya adalah bahwa baginya yang esensial dalam perjuangan pembebasan perempuan bukanlah menuntut kesetaraan, melainkan dengan membangun budaya perempuan-lelaki yang menghargai perbedaan antara kedua jenis kelamin. Oleh karena itu untuk mencapai cita-cita tersebut, Irigaray menegaskan bahwa emansipasi perempuan hanya bisa diwujudkan dengan suatu "teori tentang gender yang berlandaskan jenis kelamin dan penulisan kembali kewajiban dan hak setiap jenis kelamin, sebagai dua unsur yang berbeda dalam kewajiban dan hak sosial". Dengan ini Irigaray bermaksud menawarkan suatu upaya untuk membangun budaya perempuan-lelaki yang menghargai perbedaan antara kedua jenis kelamin.

Filosofis Irigaray bertujuan berpikir ulang mengenai simbolisme gender dan mengenai netralitas subyek rasional. Kemudian menurut Donovan dalam Natalia (2009) Irigaray bertujuan menantang konsepsi tradisional (barat) mengenai gender, diri, dan tubuh, serta menunjukkan bahwa perbedaan seksual itu tidak ada karena yang ada hanyalah laki-laki

Pemikiran Irigaray selalu terkait dengan isu politik, sosial, dan kebudayaan yang berkaitan dengan gender, baik dalam koridor akademik maupun non akademik. Hal ini terbukti melalui keterlibatan Irigaray dalam perdebatan politik kontemporer pada partai komunis di Itali. Konfrontasi yang sering terjadi lebih fokus menyoroti bagaimana tradisi budaya barat selama ini tidak memenuhi kebutuhan wanita.

Teori Irigaray mengenai perbedaan seksual berkembang dari teori subjektifitas filosofi dan psikoanalisis. Pertama, subjektifitas yang merupakan bentuk biologis atau fisik dari jenis kelamin (Pria atau wanita). Kedua, adalah bagaimana individu mengekspresikan seksualitasnya (objek feminim, maskulin, lesbian, gay atau transeksual). Irigaray menganalisis bagaimana pengalaman wanita secara konsisten dipandang rendah, ditekan atau dihilangkan dari sejarah dan teori Kultur barat. Hal ini terlihat jelas dalam analisa Irigaray bahwa filosofi dan psikoanalisis sudah salah dalam merepresentasikan wanita. Bagi Irigaray, filosofi tradisional tidak mempunyai perbedaan seksual dan wanita tidak menjadi representasi sebuah ide. Selanjutnya, Irigaray juga membantah bahwa subjek gender wanita sama sekali belum pernah ada dalam filosofi barat. Lebih lanjut Irigaray menyimpulkan bahwa wanita dan 
kualitas feminisme menjadi istilah negatif pada filosofi barat, dan subjek pria dikarakteristikan sebagai istilah positif.

Sebagai seorang post-strukturalis Perancis, Irigaray memusatkan perhatian pada kritik subjek rasional. Menurutnya, pengertian subjek dari Plato hingga Freud selalu dibangun atas dasar maskulinitas. Ini mengakibatkan perempuan menjadi warga kelas dua. Namun, tujuan Irigaray tidaklah menuntut kesamaan seperti para filsuf feminis lainnya, melainkan hal yang menjadi penekanannya adalah perbedaan. Perbedaan yang dimaksudkan ialah bahwa wanita harus mempunyai logikanya sendiri. Ketika kaum perempuan memiliki logikanya sendiri, keberadaannya sebagai manusia yang utuh dan kesetaraannya dengan kaum maskulin diperlihatkan sekaligus.

Menurut Irigaray, selama ini segala sesuatu yang diketahui oleh manusia tentang yang imajiner dan perempuan didapatkan dari sudut pandang laki-laki. Satu-satunya jenis perempuan yang dikenal adalah "perempuan yang maskulin", feminin falik, dan perempuan sebagaimana dilihat oleh laki-laki. Hal ini kemudian dikritik oleh Irigaray dan kemudian memperkenalkan bahwa terdapat jenis perempuan lain yang harus dikenali, yaitu "perempuan feminin" yang merupakan definisi perempuan sebagaimana yang dilihat oleh perempuan. Sehingga perempuan tidaklagi dianggap sama dengan laki-laki (Tong dalam Natalia, 2009). Irigaray menolak untuk memberikan definisi feminism dan lebih menyarankan bahwa apabila perempuan ingin menciptakan definisi identitas dan subjektivitas perempuan, maka perempuan harus berkumpul dengan sesamanya dan memiliki bahasa mereka sendiri.

Ide Irigaray tentang perbedaan seksual fokus pada perbedaan kondisi fisik dan psikis yang membangun subjek gender. Subjek gender dibangun dari disiplin dan organisasi institusional pengetahuan di masyarakat barat, bukan hanya hasil dari perbedaan biologis antara tubuh pria dan wanita. Irigaray mengadopsi berbagai strategi untuk mengikutsertakan ide-ide para pemikir kontemporer dan sejarawan untuk mengembangkan perhatian dan studi terhadap inovasi, kreatifitas, multidisiplin serta gender dalam arsitektur. Pada masa Irigaray aktif, terdapat dua filosofi yang berkembang terkait arsitektur, yaitu post-strukturalisme dan pemikiran politik Anglo-Amerika.

Dibawah pengaruh post-strukturalisme tersebut, para arsitek, sejarawan, dan kritikus meyakini bahwa arsitektur dibentuk dari hubungan dinamis antara perbedaan bentuk ekspresi dan pilihan partisipan. Sehingga bagi Irigaray dan para tokoh post-strukturalisme tersebut, arsitektur juga mencerminkan konstruksi kultur yang kompleks dari seseorang. Dalam pengaruh post-strukturalisme terbentuk dua sub-grup praktik arsitektural yang dapat dibedakan sebagai berikut (Rawes, 2007):

1. Tokoh yang secara eksplisit mengacu kepada pemikiran Irigaray.

Termasuk dalam subgrup ini adalah Vanessa Chase, Gülsüm Baydar, Jane Rendell, Katarina Rüedi dan Mark Wigley'. Mereka menggunakan pemikiran Irigaray untuk mengkritik arsitektur modern dalam hubungannya dengan feminisme, etnisitas, filosofi dan seni visual.

2. Tokoh yang tidak secara langsung mengacu kepada Irigaray.

Termasuk dalam subgrup ini adalah pelaku-pelaku post-strukturalisme yang rancangan bangunan, sejarah, teori dan kritiknya mencerminkan sebagian dari ide Irigaray mengenai formasi dinamis arsitektur yang bersubjek gender namun tidak secara langsung kepada pemikiran Irigaray. 
Para pelaku post-strukturalisme yang mengikuti Irigaray baik secara langsung dan tidak langsung, serta Irigaray sendiri, menolak untuk disebut sebagai feminis. Mereka menganggap feminisme bukanlah bentuk identifikasi yang paling sesuai, dikarenakan terdapat kebutuhan yang lebih kaya terkait dengan semua subjek baik fisik maupun psikologis. Sebaliknya, para pelaku Anglo-Amerika seringkali melabelkan dirinya dengan feminisme, politik-gender, dan pergerakan wanita. Hal ini disebabkan oleh adanya kebutuhan politik dalam ekonomi-sosial wanita dan golongan lain di lingkungan barat.

\section{B. Pemikiran Irigaray terkait Ruang dan Gender}

Ruang tidak terbatas pada sebuah konsep ilmiah, atau pada sebuah ide yang tak berbentuk. Menurut Irigaray dalam Rawes (2007), ilmu-ilmu fisika, matematika, dan bentuk sistematis pada arsitektur mencirikan ruang sebagai suatu yang formal, obyektif, terbagi, rasional, statis, simetris, tidak berubah, kuantitatif, program, eksternal atau diskrit. Seperti suatu yang rasional, ruang membagi dunia ke dalam sistem daerah geometris dan obyek di mana individu ditempatkan, dan dimana kesamaan dan simetri dapat mendominasi. Ia berpendapat bahwa ketika ruang didefinisikan sebagai suatu yang irasional atau abstrak, hal tersebut merupakan karakteristik wanita. Keduanya dianggap tak berbentuk, berlebihan, tidak dapat diketahui, tidak sadar, tidak dapat diakses atau terfragmentasi.

Ruang merupakan fakta eksistensial, karena kita tak bisa eksis di luar ruang, dan merupakan fenomena yang selalu terbentuk secara sosial dan dinamis (Antariksa, 2001). Segala aktivitas manusia selalu disituasikan dalam ruang tertentu, dengan makna yang berbeda-beda. Ruang tidak bersifat statis dan bukan merupakan sesuatu yang ada begitu saja, tetapi selalu terbuka bagi perubahan dan interpretasi. Formasi gender dapat mempengaruhi penggunaan dan peng-organisasian ruang. Bagaimana ruang digunakan dan dikonfigurasikan, selalu memaparkan sebuah kisah tentang manusia yang menempatinya (Wismantara, 2006).

Dalam penciptaan ruang, Irigaray berpendapat bahwa seharusnya seorang arsitek menciptakan ruang arsitektural berdasarkan perbedaan gender penggunanya. Menurut Irigaray beberapa hal penting dalam elemen arsitektur dapat dipertimbangkan dan menjadi perhatian agar tercipta ruang yang adil untuk tiap gender. Irigaray berpendapat bahwa manusia sebagai mahluk individual yang unik, begitu pun dengan desain arsitektural, selalu lebih kompleks daripada hanya sekedar kebutuhan bangunan dan ruang. Oleh karena itu, perbedaan gender pengguna menjadi penting untuk dipertimbangkan oleh arsitek.

Bagi para arsitek, kritik Irigaray tentang batas dalam representasi simbolis ruang dan waktu menjadi pertanyaan menarik seperti apakah hal tersebut memungkinkan untuk dijelaskan dalam ruang arsitektur, dan apakah aspek kehidupan dianggap berada di luar kekuasaan representasi, misalnya bagaimana konvensi arsitektur dalam menggambar, pemodelan dan menulis mengaktifkan produksi indra spasial yang berbeda?, Sesukses apakah arsitektur dalam mengembangkan ruang yang spesifik bagi pengguna apabila tidak memperhitungkan kebutuhan dan keinginan berdasarkan gender?.

Pemikiran Irigaray mengenai ruang dan gender terkait dengan adanya perbedaan bentuk tubuh antar keduanya. Perbedaan inilah yang menyebabkan penindasan atau pengecualian wanita (Lebermen, 2012). Dalam buku standar arsitektur seperti Neufert, dijelaskan konsep proporsi ruang dengan menggunakan standar tubuh laki-laki yang dikembangkan oleh Da Vinci (gambar 1). Hal tersebut merupakan salah satu contoh bagaimana tubuh wanita 
terpinggirkan dalam suatu standar ruang arsitektur. Tubuh laki-laki lebih dianggap sesuai dalam menjelaskan suatu konsep proporsional dalam desain arsitektur.

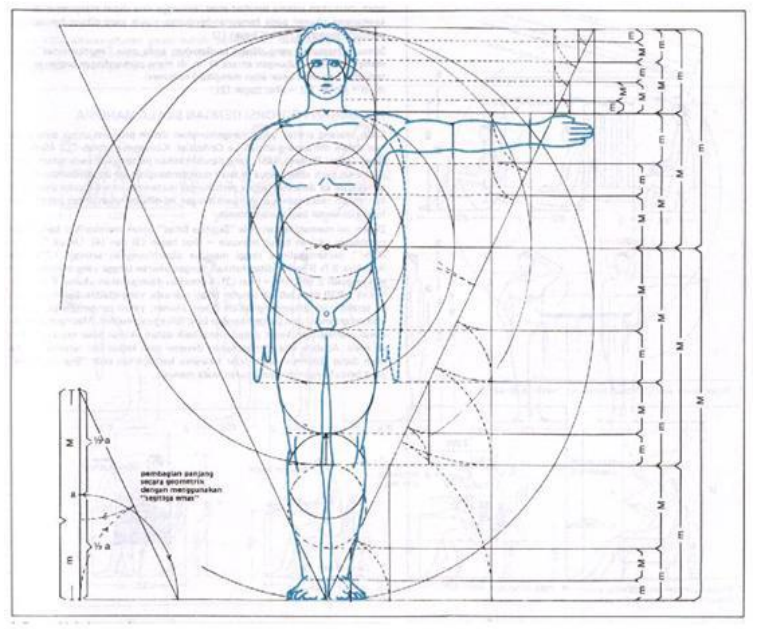

Gambar 1. Standar Universal dari Proporsi Manusia

Sumber: Neufert, 1996

Adapun hal lainnya yang merefleksikan adanya pembatasan gender dalam desain arsitektur ialah pada standar ruang untuk dapur. Dalam Neufert Standart of Architecture, standar ukuran ruang dapur hanya diidentikkan dengan tubuh wanita (gambar 2), seolah-olah menjelaskan bahwa ruangan dapur merupakan ruang yang feminim karena diidentikkan dengan wanita. Hal tersebutlah yang kemudian dikritik oleh irigaray, dimana arsitektur masih men"dewa"kan tubuh laki-laki dalam suatu standar ruang. Menurut Irigaray, hanya dengan menerima atau mengakui keunikan tubuhnya, wanita dapat dibebaskan dari tekanan ini.

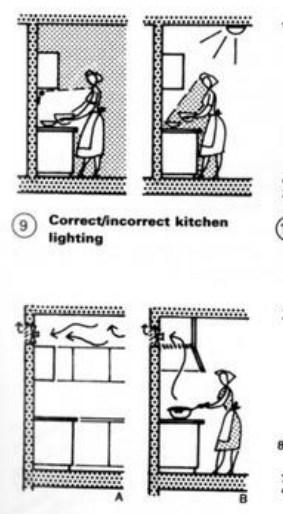

(13) Extractor fan on outer wall
(A), better if directly above
cooker (B)
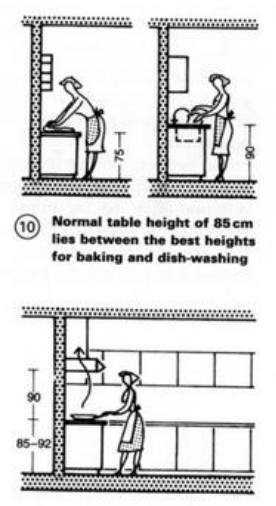

(14) Extractor

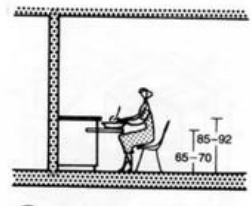

(11) Pull-out worktop for use

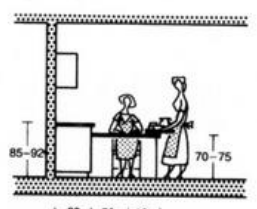

(15) Pull-out/swivelling table
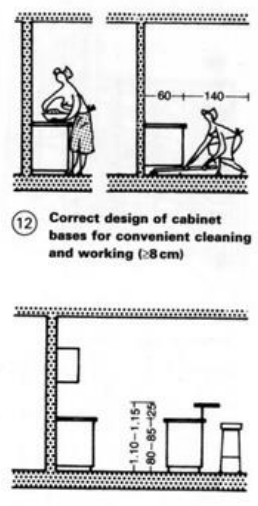

(16) A breakfast bar arrangement

Gambar 2. Standar Arsitektur untuk Ruang Dapur Sumber: Neufert, 1996

Pada tulisan ini, dipaparkan beberapa konsep yang menjelaskan hubungan pemikiran Irigaray tersebut dengan arsitektur. Lebih lanjut dijelaskan bagaimana perbedaan persepsi tubuh gender direpresentasikan kedalam desain arsitektural.

1. Konsep Fluiditas Irigaray

Salah satu pemikiran Irigaray yang diadopsi dalam teori arsitektur adalah konsep analisa psikologis/psycho-analytic terutama mengenai konsep Fluiditas. Menurut Canters dan Jantzen (2005), konsep fluiditas berkembang berdasarkan rujukan sebagai berikut: 
a. Logika yang dibangun oleh kehadiran subyek dengan jenis kelamin yang berbeda, yaitu oposisi antara biner/dikotomi maskulin yang terstruktur \& rigid dengan logika feminin yang cair

b. Subyek laki-laki dan perempuan yang menolak peran tradisional dan menetapkan batasan baru guna mengeksplorasi segala hal baru dan berbeda. Oleh karena itu subyek selalu terus menerus menjadi (becoming), selalu 'cair', selalu berkembang tanpa henti. Ke-cair-an subyek ini menjaga agar subyek tidak menjadi obyek yang rigid (dan dapat dikendalikan)

c. Bahasa yang digunakan (puitis, mempertanyakan, bermain-main, elusif, menggunakan imajeri) untuk menjaga agar pemikiran dan batasan tetap cair

d. Beyond Irigaray: mengeksplorasi perbedaan lain, perempuan yang berbeda-beda, relasi yang berbeda

Berdasarkan hal tersebut, konsep fluiditas mencoba menempatkan karakteristik fleksibilitas dalam pola pemikiran menjadi lebih 'mengalir' dan beradaptasi, namun tetap dapat dikendalikan sesuai batasannya. Karakteristik fluiditas ini dalam arsitektur teruraikan dalam bentukan dan konfigurasi ruang pada sudut pandang yang berbeda. Menurut Stone (2006) terdapat beberapa hal terkait konsep fluiditas dalam kaitannya dengan isu ruang, yaitu:

a. Merentang ruang-ruang kerja, sosial, dan pribadi yang membentuk arsitektur yang memungkinkan pertukaran yang cair

b. Menumpangtindih berbagai tingkat spasialitas

c. Berbagai isu yang menarik, mulai dari pengaturan ruang privat (di rumah) hingga konfigurasi spasial urban, serta ruang-ruang di antaranya

d. Memberi sudut pandang yang berbeda

Konsep Irigaray mengingatkan persoalan ruang terkait dengan gender, dimana wanita tumbuh dan berkembang dipengaruhi oleh bagaimana sumber dan sifat wanita. Lebih lanjut, konsep tersebut memperlihatkan bahwa subjek gender dan ruang mempunyai hubungan erat dengan konsep fluiditas. Irigaray menyarankan bahwa pengalaman ruang dan hubungan sosial manusia dapat dikonfigurasi ulang menjadi lebih bersifat cair, dengan batasan yang dapat ditembus, bukan konsep ruang yang terbatas, kaku dan tersendiri.

Konsep Irigaray mengenai fluiditas ini menjadi dasar pengembangan teori Arsitektur Cair/Fluid Architecture. Dalam perkembangannya, studi Irigaray mengenai materi gender dan komunikasi ruang memperkaya diskusi tentang produksi ruang dinamis dan hubungan sosial dalam desain arsitektur. Menurut Irigaray (1985), produksi lingkungan binaan adalah suatu organisasi sosial yang dinamis dan komplek. Arsitektur adalah sebuah proses kebudayaan dan sosial dalam ruang, dimana ruang tersebut dapat terbentuk lebih dari satu atau lebih ruang Arsitektur yang terbentuk secara bersamaan.

Irigaray pun memperlihatkan bahwa wanita keseluruhan merupakan materi jenis yang berbeda yang secara intrinsik dan perhatian terhadap pergerakan, waktu, fleksibilitas, alur, dan transformasi material aktual dari konsep ruang. Dalam konteks arsitektur dan ruang kota, Irigaray menganalisa bahwa hubungan antara individu, antara hasrat wanita atau pria dengan 
kota modern, memperlihatkan bahwa hal tersebut terdiri dari aspirasi dan materi yang tidak dapat direduksi namun dapat mengkonfigurasi ulang konsep ruang kota.

Menurut Rawes (2007), dalam "Irigaray for Architect" menyebutkan bahwa teori fluiditas Irigaray dapat menawarkan stimulasi dan energi untuk menjelajah nilai ruang dinamis untuk sebuah perkembangan arsitektur kreatif pada masa sekarang dan masa depan. Arsitek, sejarawan, teoris dan kritikus telah mempunyai keinginan untuk menguji bagaimana mengungkapkan ruang arsitektural yang bisa bersifat gender serta bagaimana hasrat feminisme membangun interior yang bernuansa intim.

Tong (2009) dalam karyanya "Feminist Thought: A More Comprehensive Introduction" mencoba menyederhanakan konsep fluiditas terhadap Arsitektur sebagai berikut :

a. Arsitektur sebagai proses desain dimana isu fluiditas sebagai masukan dalam desain

b. Arsitektur sebagai proses menghuni dimana relasi/interaksi intim yang cair antara manusia dengan ruang

c. Arsitektur sebagai Bahasa dimana bahasa Arsitektur yang bersifat lebih cair/fleksibel

d. Arsitektur sebagai 'techne' bahwa Arsitektur dipahami sebagai bukan sains dari sudut pandang ini

e. Arsitektur sebagai profesi terkait dengan kemampuan wanita sebagai arsitek professional

f. Arsitektur sebagai produk yaitu penampilan fisik yang mengikuti isu dan konsep Fluiditas.

Keterkaitan konsep fluiditas Irigaray pada arsitektur terlihat pada kemampuan sebuah material untuk bertransformasi dan berproduksi secara intrinsik terkait dengan tubuh wanita, khususnya transformasi dan produksi pada saat kehamilan, dimana menghasilkan definisi baru dari sebuah objek yang aktif, cerdas, dan sensitif. Hal ini menurut Rawes (2007) merupakan taktik yang sangat menarik untuk arsitektur, terutama untuk teori secara formal, karena dapat memikirkan kembali konsep ruang yang mempertimbangkan sebuah material menjadi tanpa bingkai hingga terbentuk dan teraktivasi sendiri oleh ide atau bentuk dari eksternal.

Terdapat beberapa contoh desain arsitektur menurut Rawes (2007) terkait dengan konsep fluiditas dan ruang Irigaray. Contoh-contoh desain arsitektur ini secara bersamaan terdapat bentukan ruang arsitektural yang bersifat pribadi dan sosial, yang memberikan konsep pertukaran/fleksibilitas pergerakan sifat zat cair. 
a. Mobius House' (1998) oleh Caroline Bos dan Ben van Berkel's
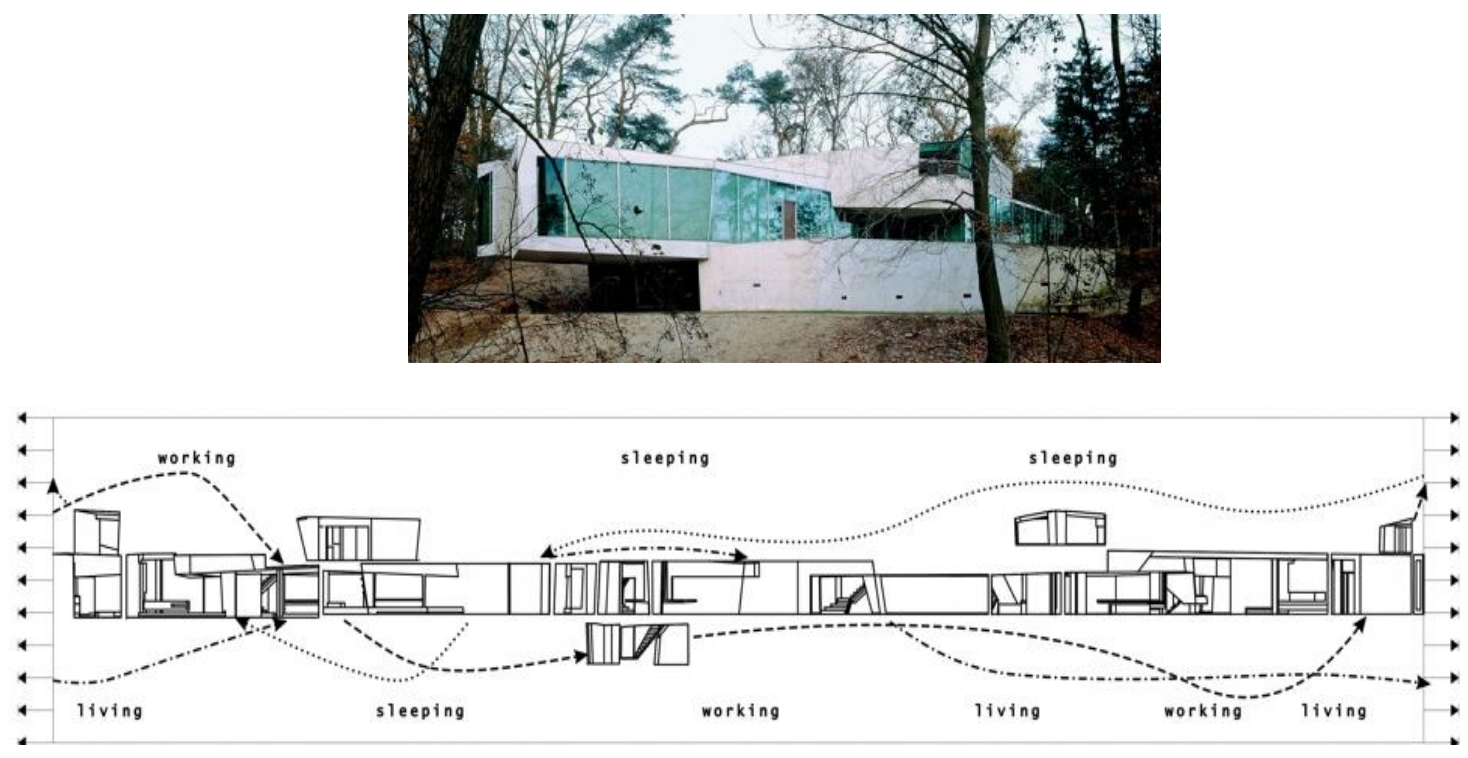

(a)

eksterior

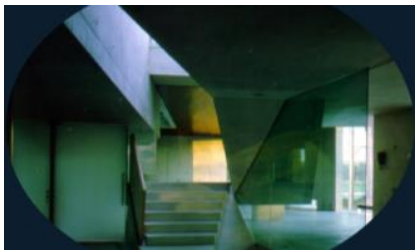

(b)

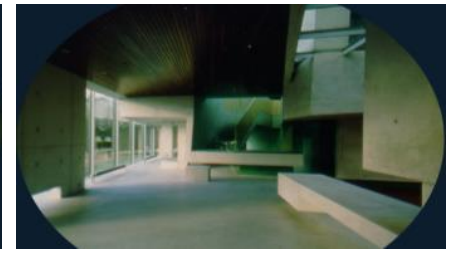

Interior

Gambar 3. Mobius House

Sumber: http://storiesofhouses.blogspot.com/2006/09/mbius-house-in-amsterdam-by-ben-van.html, diakses pada 17 Mei 2015)

Dalam desainnya, Berkel dan Bos memahami bahwa bahasa arsitektur baru pada saat itu seharusnya menjadi konsekuensi baru juga terhadap gaya hidup. Adanya perpindahan dan pergerakan dari masing-masing pengguna bangunan pada saat bersamaan, namun tetap terelaborasi dalam satu kesatuan, menjadi satu tantangan dalam mewadahinya dalam suatu produk arsitektur. Rumah sebagai suatu prroduk arsitektur seharusnya "dijahit" bersamaan dengan berbagai kebutuhan dan aktifitas yang berbeda dari setiap anggota keluarga yang kemudian disatukan dalam diagram kehidupan sehari-hari. Pertimbangan dari durasi dan waktu merupakan konsep terpenting dari awal proses desain. Konsep pergerakan, pertukaran dan fleksibilitas ruang menjadi benang merah dalam hubungan desain bangunan ini yang diinspirasi oleh konsep fluiditas Irigaray (Arnadotir, 2006).

b. 'Wrap House' (2004-2005) oleh Alison Brooks Architects

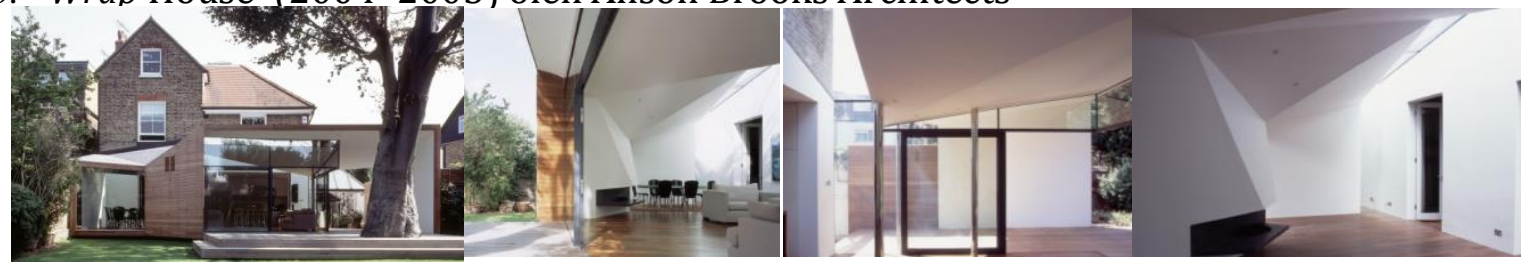

Gambar 4: Eksterior (a) Wrap House (b)

(Sumber: http://www.alisonbrooksarchitects.com/project/wrap-house/ diakses pada 17 Mei 2015) 
Alison Brooks Architects mengembangkan sebuah perluasan rumah di kota London dengan luasan $100 \mathrm{~m} 2$ pada lantai dasarnya. Desain ini mendapatkan peng-hargaan bergengsi dari RIBA Stephen Lawrence Price. Desain dengan analogi bentuk pita ini menciptakan bentukan atap yang cukup menarik yang dapat dinikmati langsung dari tempat tidur utama. Konsep dari "Wrap House" dikembangkan dari distorsi permukaan tunggal menjadi sebuah pita terlipat yang menciptakan rangkaian ruang internal yang menerus.

Konsep ini selaras dengan penjabaran mengenai sifat fluiditas Irigaray dimana adanya pergerakan natural zat cair yang mengalir pada setiap ruang yang diciptakan dengan fleksibilitas dan kesimbangan yang dinamis.

c. Fire Station Five (1984-1987), Columbus, Indiana oleh Susana Torre

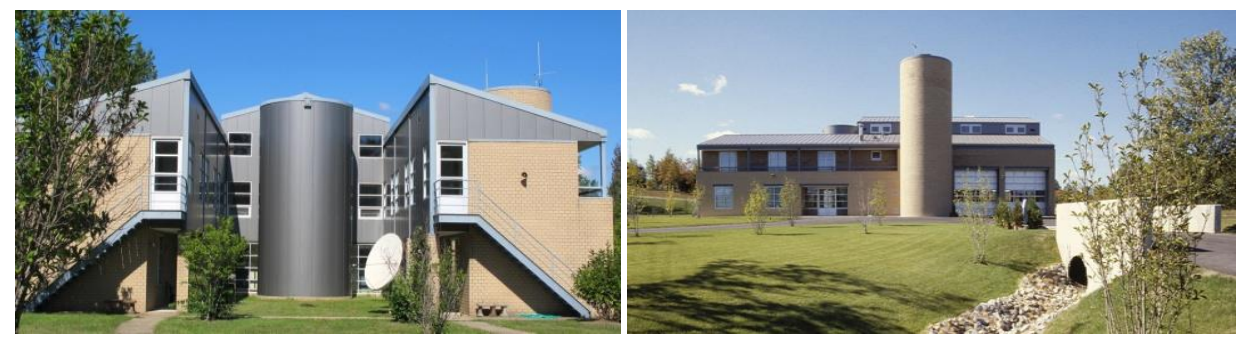

Eksterior (a) tampak depan (b) Tampak belakang

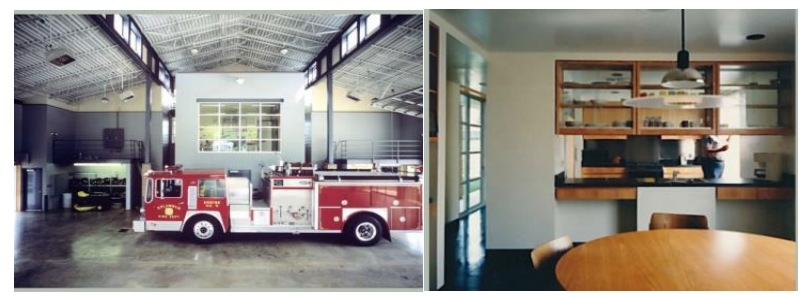

Interior - garasi dan kantor

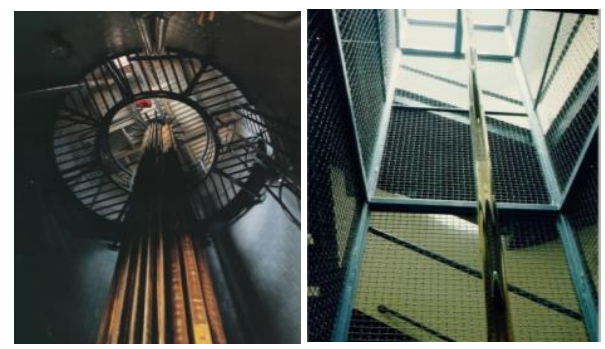

Interior - Akses Vertikal

Gambar 4. Fire Station Five

Sumber: http://www.susanatorre.net/architecture-and-design/making-room-for-women/fire-station-five/, diakses pada 17 Mei 2015

Bangunan Stasiun Pemadam Kebakaran di Colombus-Indiana, Amerika Serikat ini, merupakan salah satu perwujudan konsep kesetaraan gender untuk wanita khususnya dibidang jasa pemadam kebakaran. Komitmennya adalah sebagai kesempatan untuk menciptakan dan memikirkan kembali konsep bangunan tipe ini yang dapat mengintegrasikan kebutuhan wanita.

Pembagian dan pengorganisasian spasial dari bangunan ini untuk kebutuhan makan, latihan dan istirahat yang secara 24 jam berbagi bersama antara pria dan wanita menjadi tantangan tersendiri desain bangunan ini.

Bangunan ini berbentuk huruf ' $U$ ' yang menghilangkan tipologi bangunan asrama dan menempatkan penyatuan silang gender di area dapur dengan menstruktur ulang ruang- 
ruang umum/sosial untuk memfasilitasi kolaborasi gender. Tipologi desain ini kemudian menjadi banyak diadopsi di dunia Arsitektur.

\section{Persepsi melalui Sentuhan}

Hubungan manusia dan ruang lainnya yang dibahas oleh Irigaray terkait dengan konsep persepsi. Persepsi merupakan suatu gambaran akan apa yang dirasakan melalui tubuh. Pada suatu ruang yang berbeda, persepsi yang muncul pun akan berbeda. Persepsi terhadap ruang bukan sekedar melihat bagaimana perbandingan ukuran ruang terhadap tubuh kita, namun lebih kepada bagaimana perasaan dan persepsi tentang ruang yang ada. Tubuh manusia berfungsi sebagai alat ukur bagi perasaan yang akan dirasakan terhadap suatu ruang. Sensor dari tubuh manusia dapat menyimpulkan suatu keadaan ruang dalam bentuk persepsi dan perasaan.

Pemikiran Irigaray memberikan sumbangsih dalam pengembangan konsep persepsi melaui panca indera. Konsep ini kembali dievaluasi dengan memasukkan unsur peraba dan suara dalam arsitektur modern (dapat dilihat dalam tulisan Juhani Pallasma, The eyes of the Skin, 2005). Menurut Irigaray, persepsi sentuhan sebaiknya lebih dipertimbangkan daripada persepsi visual. Dia menunjukkan bahwa pemikirannya melalui sentuhan merupakan gaya baru dalam mengekspresikan interaksi gender dengan orang lain dan dengan material dan ruang.

Sebelumnya, persepsi melalui sentuhan merupakan tingkatan persepsi yang paling rendah. Dalam hirarki lima panca indera oleh Aristoteles, indera yang paling tinggi ialah penglihatan dan yang paling rendah ialah peraba. Pemikiran Irigaray menolak aliran yang dikembangkan oleh Plato. Adapun menurut Irigaray dalam tulisannya menyatakan bahwa lingkungan terbentuk melalui persepsi panca indera, terutama sentuhan. Dari pemikiran tersebut, ditunjukkan bahwa hubungan spasial antara manusia dan lingkungan dapat terbangun dari persepsi melalui panca indera, terutama sentuhan. Persepsi ruang melalui sentuhan menjelaskan bahwa tidak ada batasan terhadap suatu ruang dan tidak dapat diukur secara kuantitatif.

Irigaray juga menolak disejajarkannya unsur visual dan peraba. Menurutnya, kedua hal tersebut memiliki logika tersendiri, walaupun terkadang overlap satu sama lainnya. Suatu unsur penglihatan terdapat dalam unsur peraba, namun unsur peraba dapat berdiri sendiri tanpa adanya unsur penglihatan. Hal ini dapat dipelajari dari fenomena orang buta, dimana mereka dapat memperoleh informasi dari suatu objek tanpa adanya unsur penglihatan (Grosz, 1993).

Pemikiran Irigaray tercermin pada beberapa desain kontemporer, dan penelitian mengenai teori dan sejarah terkait pengalaman sentuhan, pendengaran dan penciuman terhadap ruang dan material arsitektur. Hal ini dapat terlihat pada desain arsitektur yang mempertimbangkan pengalaman ruang, seperti desain akustik dan ruang terapi, serta pada pengembangan material yang dinamis (material plastik yang merespon panas) dan desain arsitektur yang yang merespon kebutuhan pengguna dan lingkungan sekitarnya (Rawes, 2007).

Dalam kaitannya dengan perbedaan gender, terdapat perbedaan dalam mempersepsikan ruang melalui sentuhan antara pria dan wanita. Wanita dianggap lebih peka terhadap sensitivitas spasial, karena dapat mempersepsikan ruang melalui sentuhan secara langsung melalui panca indera mereka, sedangkan laki-laki tidak dapat mempersepsikan objek melalui sentuhan melalui unsur perabanya secara langsung.

Dalam pemikiran ini, Irigaray memberikan kritik terhadap dua filsuf yang juga mengembangkan teori tentang sentuhan, yaitu Merleau-Ponty dan Levina. Menurut Irigaray pemikiran Maurice Merleau-Ponty tentang "tubuh seksual", ialah fenomenologi pesimistik, Irigaray juga menilai Ponty melupakan fungsi seksualitas sebagai suatu 
hubungan-dengan (a relationship-to), sekaligus mengabaikan persepsi sebagai sarana untuk menyambut yang lain sebagai yang lain (other).

Padahal melalui persepsi, menurut Irigaray manusia bisa melihat, mengenal dan lebih menghormatinya orang lain sebagai subjek, tanpa harus mengurangi nilainya sebagai subjek. Demikian juga dalam relasi kebertubuhan, manusia sama sekali bukanlah sosok subjek yang mencari objek dalam diri orang lain. Melainkan telah menyadari adanya relasi dialektik subjektifitas dan objektifitas itu dalam dan bagi dirinya dan orang lain, tanpa suatu dikotomi subjek-objek. Dalam hubungan subjektif ini, masing-masing diri saling merawat dan menumbuhkan kejatidirian masing-masing.

Bagi para arsitek pemikiran irigaray mengenai perbedaan dalam persepsi sentuhan ini, membuka jalan dalam perkembangan konsep mengenai Tactile Space. Konsep ini muncul karena keinginan adanya keseimbangan dalam cara mempersepsikan ruang melalui visual dan sentuhan. Lebih lanjutnya, pemikiran Irigaray juga memberikan pengaruh terhadap perkembangan industri material bangunan. Tekstur dari material pun menjadi penting untuk dipertimbangkan dalam mewujudkan tactile space.

Dari kedua konsep hasil pemikiran Irigaray, yaitu fluiditas dan persepsi melalui sentuhan, keduanya menjelaskan bagaimana perbedaan gender dalam suatu ruang menentukan bentukan dari suatu produk arsitektur. Apabila arsitek telah dapat mewadahi perbedaan kebutuhan antar gender, maka karya tersebut telah mengakui kedua gender sebagai subyek yang diwadahi dalam suatu produk arsitektural, bukanlah lagi sebagai objek.

Pengakuan individu sebagai subyek dalam arsitektur dapat diwujudkan dengan melibatkan pengguna dalam proses desain. Para arsitek dapat mencari tahu kebutuhan pengguna ruang secara langsung dari masing-masing individu dan kemudian menerjemahkannya kedalam desain. Adanya perbedaan kebutuhan antar individu seharusnya merupakan sesuatu yang menarik untuk diwujudkan, namun kecenderungan saat ini, para arsitek menggeneralisasikan kebutuhan ruang pengguna dalam suatu standar umum. Hal inilah yang dikritik oleh Irigaray karena tidak mempertimbangkan perbedaan gender penggunanya

\section{KESIMPULAN}

Irigaray mengembangkan pemikirannya dalam menganalisa bagaimana kultur kebudayaan dan bahasa menempatkan laki-laki dan perempuan secara berbeda. Irigaray menawakan suatu perspektif yang baru dalam memandang segala sesuatunya. Irigaray meyakini bahwa perbedaan antara laki-laki dan perempuan tidak akan pernah disetarakan maupun dimasukkan ke dalam istilah-istilah atau konsepsi yang sama. Perbedaan ini merupakan hal yang harus diakui oleh kedua belah pihak dan dimaknai bukan sebagai dominasi atas yang lain.

Pemikiran Irigaray mengenai perbedaan gender pun dikaitkan dengan ruang dalam arsitektur. Formasi gender dapat mempengaruhi penggunaan dan peng-organisasian ruang. Bagaimana ruang digunakan dan dikonfigurasikan, selalu memaparkan sebuah kisah tentang manusia yang menempatinya. Irigaray berpendapat bahwa seharusnya seorang arsitek menciptakan ruang arsitektural berdasarkan perbedaan gender penggunanya. Menurut Irigaray, beberapa hal penting dalam elemen arsitektur dapat dipertimbangkan dan menjadi perhatian agar tercipta ruang yang adil untuk tiap gender.

Konsep fluiditas dari Irigaray mencoba menempatkan karakteristik fleksibilitas dalam pola pemikiran menjadi lebih 'mengalir' dan beradaptasi, namun tetap dapat dikendalikan sesuai batasannya serta mempunyai karakteristik yang teruraikan dalam bentukan dan konfigurasi ruang pada sudut pandang yang berbeda. Dengan konsep ini, Irigaray menyarankan bahwa 
pengalaman ruang dan hubungan sosial manusia dapat dikonfigurasi ulang menjadi lebih bersifat cair dan fleksibel, bukan konsep ruang yang terbatas, kaku dan tersendiri.

Konsep lainnya yang lahir dari pemikiran Irigaray ialah persepsi ruang melalui sentuhan. Dalam kaitannya dengan perbedaan gender, terdapat perbedaan dalam mempersepsikan ruang melalui sentuhan antara pria dan wanita. Menurut Irigaray, persepsi sentuhan sebaiknya lebih dipertimbangkan daripada persepsi visual. Dia menunjukkan bahwa pemikirannya melalui sentuhan merupakan gaya baru dalam mengekspresikan interaksi gender dengan orang lain dan dengan material dan ruang. Bagi para arsitek pemikiran Irigaray mengenai perbedaan dalam persepsi sentuhan ini, membuka jalan dalam perkembangan konsep mengenai Tactile Space yang muncul karena keinginan adanya keseimbangan dalam cara mempersepsikan ruang melalui visual dan sentuhan.

Dalam dunia arsitektur, pemikiran Irigaray berguna untuk mencipatakan suatu karya arsitektur yang lebih humanis. Bagaimana perbedaan gender dapat diwadahi dalam suatu ruang dalam arsitektur merefleksikan bahwa adanya pengakuan terhadap kedua subjek gender manusia sebagai pengguna produk arsitektur. Hal ini dapat diwujudkan dengan melibatkan pengguna atau klien dalam proses perancangan arsitektur. Kebutuhan penghuni seharusnya tidak digeneralisasikan secara umum dalam suatu standar desain, namun lebih kepada mengetahui kebutuhan dari masing-masing pengguna dan mengelaborasikannya ke dalam suatu wadah arsitektural.

\section{DAFTAR REFERENSI}

Antariksa. 2001. Politik Ruang. Newsletter Kunci, Edisi 9, Jogjakarta.

Canters, H., \& Jantzen, G. M. 2005. Forever Fluid: A Reading of Luce Irigaray's Elemental Passions. Manchester: Manchester University Press

Grosz, Elizabeth. 1993. Merleau-ponty and Irigaray in the flesh. Thesys MIT

Leberman, Alyson. 2012. Accessing Women through Masculine Discourse: Luce Irigaray's Embodied Syntax. Philosophy Senior Thesis of Haverford College

Natalia, Stephanie. W. 2009. Keterangan Perempuan di dalam Subjektivitas Maskulin: Sebuah Analisa Kritis atas Tatanan Simbolis Jacques Laca. Skripsi Universitas Indonesia Depok.

Patterson, Mark. 2007. The Sense of Touch: Haptics, Affects and Technology. Berg. London

Prabasmoro, Aquarini P. 2005. Feminisme sebagai Tubuh, Pemikiran, dan Pengalaman. Studi Kebudayaan, FSRD ITB.

Rawes, Peg. 2007. Irigaray for Architects. Routlede Taylor and Francis Group, London and New York.

Stone, Alison. 2006. Luce Irigaray and the Philosophy of Sexual Difference. Cambridge: Cambridge University Press

Tong, Rosemary. 1989. Feminist Thought: A Comprehensive Introduction. London: Unwin Hyman Wismantara, Pudji.P. 2009. Politik Ruang Gender pada Permukiman Taneyan Lanhang Sumenep. Jurnal Kesetaraan dan Keadilan Gender, Pusat Studi Gender (PSG) Universitas Islam Negeri Maulana Malik Ibrahim, Malang 